\title{
Střednopleistocenní sesuv na svazích Drahanské vrchoviny u Viničných Šumic
}

Middle Pleistocene landslide on the slopes of the Drahany Highlands close to Viničné Šumice village

\section{Pavla Tomanová Petrová' $\hookrightarrow$, , Oldřich Krejčí', Nela Doláková2, Helena Gilíková', Šárka Hladilová ${ }^{3}$, Kamil Zágoršek ${ }^{4}$}

'Česká geologická služba, Leitnerova 22, 65869 Brno

2 Ústav geologických věd, Přirodovědecká fakulta, Masarykova univerzita, Kotlářská 2, 61137 Brno

${ }^{3}$ Katedra biologie, Pedagogická fakulta, Univerzita Palackého, Purkrabská 2, 77140 Olomouc

${ }^{4}$ Katedra geografie, Fakulta prírodnè-humanitní a pedagogická, Technická Univerzita v Liberci, Studentská 1402/2, 461 17 Liberec 1

Key words:

Lower Badenian, Carpathian Foredeep, landslides, Foraminifera, Bryozoans, Molluscs, Palynology

$\checkmark$ pavla.petrova@geology.cz

Editor:

Martin Ivanov

\begin{abstract}
In 2018 an excavation of $20 \times 20 \mathrm{~m}$ large and up to $5 \mathrm{~m}$ thick calcareous clays of the Langhian age was found. Rich and diversified assemblages of foraminifers with species Orbulina suturalis Brön. and Martinotiella karreri (Cush.) indicate early Badenian (in sense of the Central Paratethys regional stratigraphy) age of the sediments, zone M5b sensu Berggren et al. (1995). Variously deformed lenses and layers of fine-grained sand with several blocks of white calcareous silts and with two layers of clayey sediments with pebbles were found. The identified outcrop is part of a large landslide situated at the western margin of the Carpathian Foredeep. Samples determining the age of the landslide movements were taken from Badenian clays and from slope sediments with pebbles for study of palynomorphs. Very rich and diversified fauna was described mainly from the fine-grained sand creating layers in calcareous clays. The assemblage contained tests of foraminifers, spines of the echinoids, fragments of sponge spicules, rich fragments of molluscs and zoarias of bryozoas, worms - Ditrupa cornea (Linnaeus, 1758), Serpula sp., ?Serpulidae indet., fragments of brachiopods, arthropods, coral, ostracods, teleostei etc.

The findings from the Badenian and Quaternary periods were mixed by slope movements. Large landslide in the Middle Pleistocene was the terminal gravity proces in the area of Viničné Šumice.
\end{abstract}

Doporučená citace článku: Tomanová Petrová, P., Krejčí, O., Doláková, N., Gilíková, $H$., Hladilová, Š., Zágoršek, K. (2019). Střednopleistocenní sesuv na svazích Drahanské vrchoviny u Viničných Šumic. - Geologické výzkumy na Moravě a ve Slezsku., 26, 1-2, 116-123.

DOI: https://doi.org/10.5817/ GVMS2019-1-2-116
Úvod

$\mathrm{V}$ roce 2018 byl během výkopových prací na pozemku rodinné pekárny KULHÁNEK \& DRÁPAL s.r.o. mezi obcemi Viničné Šumice a Vítovice (v. od Brna - obr. 1) odkryt zářez o velikosti $20 \times 20$ m a výšce stěny místy až do $5 \mathrm{~m}$. Zářez odkryl vápnité jíly badenského stáří, ve kterých byly různě deformované čočky a polohy jemnozrnného písku s několika bloky bílých vápnitých prachů (slínů) a s 2 polohami hlinitých sedimentů s valouny (obr. 2). Výchoz je součástí rozsáhlého sesuvu situovaného při z. okraji karpatské předhlubně. Z obou poloh písčitoprachovitých sedimentů (svahovin), které se nacházejí uvnitř deformovaných badenských jílů, byly odebrány vzorky na určení palynomorf za účelem zjištění stáří sesuvných pohybů. Souběžně byla $\mathrm{z}$ jílů až písků zpracována bohatá mikrofauna.

V současné době je již výkop zasypán a zastavěn.

\section{Geologie širšího okolí}

Podle regionálně-geologického členění ČR se širší okolí lokality nachází na rozhraní dvou geologických jednotek Českého masivu a karpatské předhlubně. 


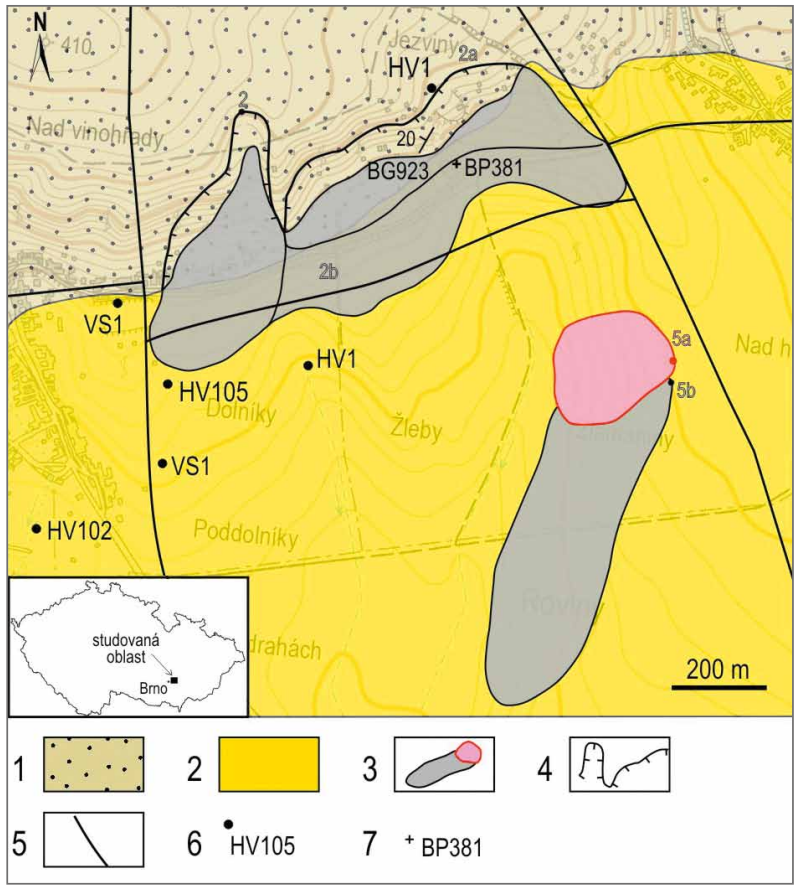

Obr. 1: Pozice studované lokality (dokumentační bod BP381), geologická stavba se zákresem studovaného sesuvu a vrty z vrtné databáze [zdroje: https://mapy.geology.cz/vrtna_prozkoumanost/, www.geology.cz/svahovenestability, geologická mapa upravena podle podle Gilíkové, Hladila eds et al. (2011a) a Brzobohatého, ed. (1989)]. Legenda: 1 - myslejovické souvrství; 2 - spodnobadenské jíly; 3 - sesuvy, červeně sesuv aktivní; 4 - odlučná hrana; 5 - zlomy; 6 - vrty; 7 - dokumentační bod. Fig. 1: Position of the locality (reference point BP381), geological structure with a plot of the landslide and boreholes from the drilling database [sources: https://mapy.geology.cz/vrtna_prozkoumanost/, www.geology.cz/svahovenestability, geological map modified by by Gilíková, Hladil eds et al. (2011a) and Brzobohatý, ed. (1989)]. Legend: 1 - the Myslejovice Formation; 2 - Lower Badenian clays; 3 - landslides; active landslide (red); 4 - rupture zone; 5 -faults; 6 - boreholes; 7 - reference point.
Na svazích v okolí Viničných Šumic, vč. Hynčicovy skály, vystupují sedimenty paleozoika Drahanské vrchoviny (obr. 1). Jedná se o flyšové sedimenty myslejovického souvrství spodnokarbonského stáří, resp. o račické slepence, ve kterých se vyskytují občasné polohy drob (Gilíková, Hladil eds et al. 2011a, b). Sedimentace račických slepenců odpovídá goniatitové zóně Goo a v nejvyšší části zóně Goß

Karpatská předhlubeň je v zájmovém území nejčastěji (plošně i vertikálně) zastoupena sedimenty spodního badenu. Jejich souvislý výskyt je omezen na j. okraj území zhruba po linii Brno-Hády-Líšeň-Horákov-Pozořice-Viničné Šumice-Luleč. V rousínovsko-vyškovském úseku dílčí badenské předhlubně jsou známé mocnosti těchto sedimentů přes $600 \mathrm{~m}$ (vrt Rousínov $1-665 \mathrm{~m}$; Adamová et al. 1975).

Na základě litologického složení lze uloženiny badenu rozdělit na facii bazálních klastik a pelitickou $s$ převahou vápnitých jílů. Facie bazálních klastik je zejména při okraji pánve tvořena písky a štěrky. Změna bazálních klastik do nadložní pelitické facie svědčí o náhlém prohloubení pánve. Ve vyšších částech paleoreliéfu transgredují jíly př́mo na paleozoikum.

Podle litologického profilu hydrogeologického vrtu HV-105 (Skoupilová 1974), který byl odvrtán při j. okraji sesuvného území, se ve svrchní ćásti profilu spodnobadenskými sedimenty do hloubky 133,5 m nachází vápnité jíly, pod nimiž se až do do konečné hloubky $160 \mathrm{~m}$ vrtu nacházejí bazální pískovce a písky.

Kontakt sedimentů spodního badenu při sz. okraji karpatské předhlubně s paleozoikem Drahanské vrchoviny je transgresívní, ale byl také silně ovlivněn aktivitou podél okrajového zlomu karpatské předhlubně jz.-sv. směru. Tento zlom je významnou tektonickou strukturou prvního řádu (linie A25; Bližkovský et al. 1988) a je porušen četnými mladšími zlomy jv.-sz. směru (obr. 1).

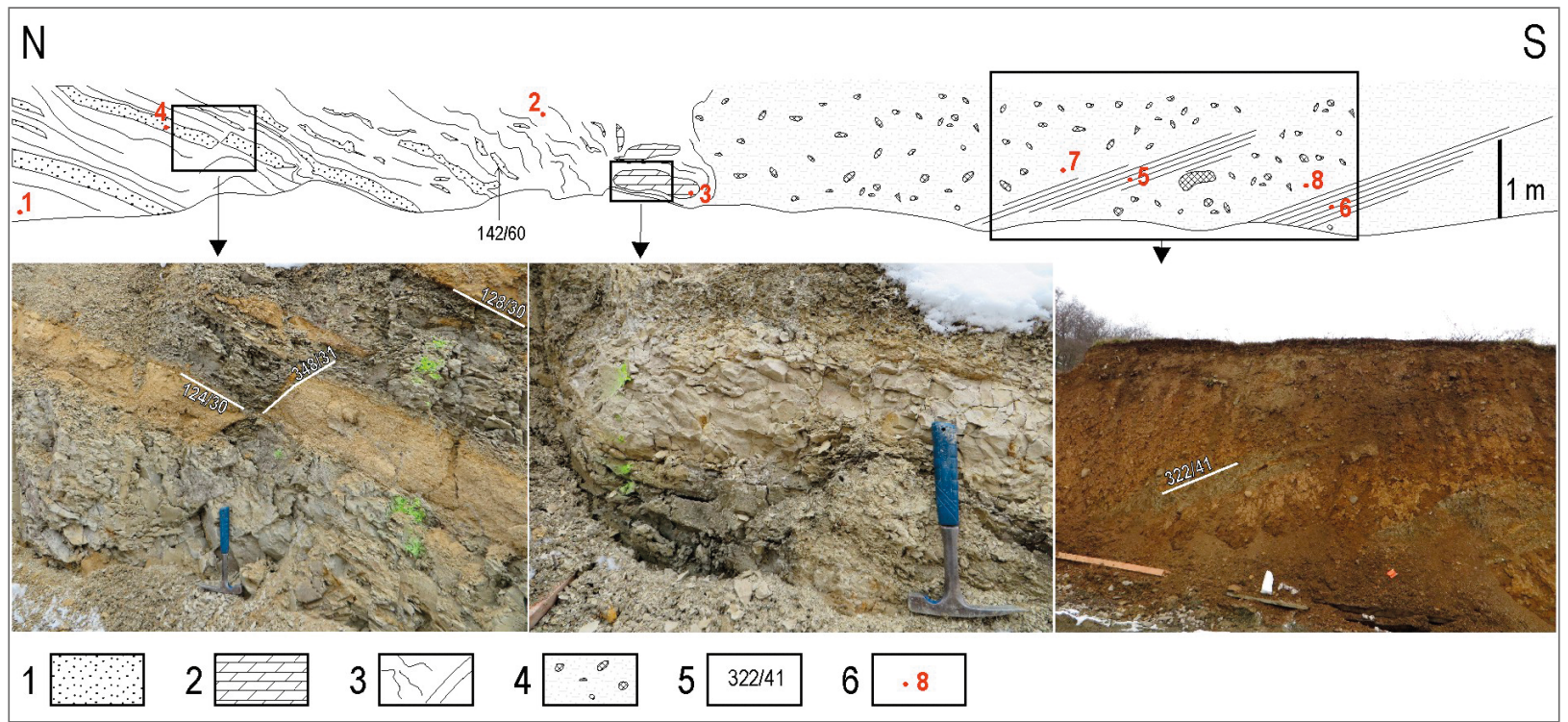

Obr. 2: Zobrazení vztahů sedimentů studované lokality s pozicemi studovaných vzorků 1/18-8/18 (nakresleno na základě fotografií). Legenda: 1 - písky; 2 - prachy; 3 - jíly; 4 - svahoviny; 5 - strukturní měření; 6 - místo odběru vzorku.

Fig. 2: Sketch of relations of sediments of the studied locality with the positions of studied samples 1/18-8/18 (drawn on the basis of photographs). Legend: 1 - sands; 2 - silts; 3 - clays; 4 - colluvial deposits; 5 - structural measurement; 6 - sample position. 
Svahy sz. okraje karpatské předhlubně byly pro svou strmost velmi nestabilní a již během badenu docházelo ke vzniku rozsáhlých kerných sesuvů, které byly postupně stabilizovány nárůstem mocnosti badenských sedimentů výplně karpatské předhlubně.

Výraznou pokleslou krou z tohoto období je např. kra, na níž byl odvrtán vrt HV-105, kde je dosud přesně nezjištěná vysoká mocnost miocenních sedimentů (přes $160 \mathrm{~m}$ ). V období svrchního miocénu, pliocénu a kvartéru docházelo dále k vývoji sesuvů na strmých svazích pánve karpatské předhlubně, tyto sesuvy však již nikdy nedosáhly rozměrů sesuvů $\mathrm{z}$ období sedimentace spodního badenu a těsně po ní.

\section{Metodika}

Vykopaný odkryv byl zdokumentován dle standardních mapovacích geologických prací a zaznamenán do databáze dokumentačních bodů ČGS (dokumentační bod BP381, GPS: N 49¹3.02155', E 1650.28138`). Z výchozu byly postupně odebrány vzorky $1 / 18-8 / 18$ (pozice vzorků viz obr. 2) k dalšímu zpracování.

Vzorky na mikropaleontologická studia (foraminifery, mechovky, měkkýši) byly namočeny do roztoku jedlé sody a vyplaveny na sítu o velikosti ok $0,063 \mathrm{~mm}$. Následně byla rezidua studována pod binokulárním mikroskopem NIKON SMZ 745T, byly vybrány fosilie a determinovány. Pro studium foraminifer bylo zpracováno celkem 8 vzorků (1/18-8/18). Měkkýši a mechovky byly studovány ze vzorku $4 / 18$. Vzorky pro palynomorfy byly odebrány $\mathrm{z}$ písčitoprachovitého sedimentu $\mathrm{z}$ bodů $7 / 18$ a 8/18. Palynomorfy byly ze sedimentů získány macerací za pomoci $10 \% \mathrm{HCl}$ (po dobu 24 hod.) a $30 \% \mathrm{HF}$ (po dobu 2 dnů). Pro zkoncentrování obsahu palynomorf bylo využito těžké kapaliny $\mathrm{ZnCl}_{2}$. Determinace palynomorf byla prováděna optickým mikroskopem Nikon Alphaphot 2. Z obou vzorků byly studovány vždy 3 mikroskopické preparáty.

Pro detailní vymezení dílčích sesuvných okrsků byla využita datová sada ZABAGED (ZM 10, polohopis a 3D vrstevnice) a digitální model reliéfu České republiky 5. generace (DMR 5G), který představuje zobrazení přirozeného nebo lidskou činností upraveného zemského povrchu v digitálním tvaru ve formě výšek diskrétních bodů $\mathrm{v}$ nepravidelné trojúhelníkové síti (TIN) bodů o souřadnicích $\mathrm{X}, \mathrm{Y}, \mathrm{H}$, kde $\mathrm{H}$ reprezentuje nadmořskou výšku ve výškovém referenčním systému Balt po vyrovnání (Bpv) se střední chybou výšky $0,18 \mathrm{~m}$ v odkrytém terénu a $0,3 \mathrm{~m}$ v zalesněném terénu. Model vznikl $\mathrm{z}$ dat pořízených metodou leteckého laserového skenování reliéfu území ČR v letech 2009 až 2013.

\section{Výsledky a interpretace 1. Litologie}

Těsně nad dokumentovaným výkopem vystupuje skalní stěna (PP Hynčicova skála - http://lokality.geology.cz/4149), která je budována račickými slepenci, ve kterých jsou drobné drobové polohy (dokumentační bod BG323). Slepence jsou polymiktní, zrnitostně špatně vytříděné a mají převažující podpůrnou strukturu dobře opracovaných valounů. Bylo pozorováno pozitivní gradační zvrstvení dané zmenšováním velikosti valounů s max. velikostí valounů $60 \mathrm{~cm}$ (v ose a). Ve valounovém materiálu převažují ruly, křemeny, kulmské sedimenty (droby, břidlice) a granitoidy. Sedimentární vrstvy jsou většinou ukloněny pod úhlem $20^{\circ} \mathrm{k} \mathrm{SV}$, což přibližně odpovídá vrstevnatosti v této oblasti (Gilíková, Hladil eds et al. 2011a, b). Skalní výchoz PP Hynčicovy skály je výrazně postižen křehkou deformací - puklinami. Nejhojněji jsou zastoupeny otevřené pukliny v.-z. směru (resp. sz.-jv.), pravděpodobně spojené se systémem okrajových zlomů karpatské předhlubně. Ačkoliv výchozy račických sedimentů jsou nedaleko kopaného zářezu, v samotném (až $5 \mathrm{~m}$ hlubokém výkopu) nebyly zachyceny. Kulmský materiál se objevil pouze ve valounech (valouny až okolo $30 \mathrm{~cm}$ ) ve dvou polohách písčitoprachovitých sedimentů (svahovin), které byly zdokumentovány uvnitř badenských jílů.

V severní části výkopu byly především zachyceny různě deformované šedozeleně zbarvené vápnité jíly. V těchto jílech se vyskytovaly různě mocné čočkovité nebo i průběžné polohy jemnozrnného rezavě hnědého vápnitého silně slídnatého, drobně paralelně laminovaného písku (odběrový vzorek 4/18). V této části výchozu vrstvy upadají pod úhlem $30^{\circ} \mathrm{k} \mathrm{JV}$ (obr. 2). Směrem k J se vrstvy vzpřičují až do úklonu $60^{\circ}$. Uprostřed výchozu byly $\mathrm{v}$ jílech zdokumentovány 3 bloky (až $1 \mathrm{~m}$ velké) hnědobílého silně vápnitého prachovce (odběrový vzorek 3/18).

V jižní části výkopu převažoval hnědožlutý písčitoprachovitý sediment $\mathrm{s}$ valouny kulmských drob až $30 \mathrm{~cm}$ velkých a s útržky jílů (odběrové vzorky 7/18 a 8/18). Písčitoprachovitý sediment nejevil žádnou vrstevnatost, zrnitostní vytrríděnost sedimentu byla velmi nízká. Uvnitř těchto prachů byly zachyceny 2 polohy zelenošedých vápnitých prachových jílů od svahovin ostře oddělených (odběrové vzorky $5 / 18$ a 6/18), které obsahovaly bohatou badenskou mikrofaunu (viz níže). V této části zářezu ale jílové polohy jevily opačný (protiklonný) směr vrstevnatosti, než bylo zaznamenáno $\mathrm{v}$ s. části zářezu, a to $\mathrm{k} \mathrm{SV}$ $(322 / 41)$.

\section{Paleontologie \\ 2.1 Neogenní jíly}

Hnědošedé nazelenalé vápnité prachovité jíly (vz. 1/18, 2/18, 5/18 a 6/18) obsahují bohatou mikrofaunu zastoupenou foraminiferami, fragmenty schránek měkkýšů, ostny i destičkami ježovek, schránkami ostrakodů a vzácně otolity. Rezidua jsou tvořena především schránkami fosilií, popříp. zrny křemene, slídou a oxidy a hydroxidy železa.

\section{Foraminifery}

Společenstvo foraminifer představuje typickou spodnobadenskou faunu s dominujícím planktonem s často drobnými, místy limonitizovanými schránkami. Biostratigraficky významné druhy Orbulina suturalis Brön. a Martinotiella karreri (Cush.) jej řadí do spodního badenu do zóny M5b ve smyslu Berggren et al. (1995). Dále se vyskytují druhy obvyklé ve spodním badenu jako např. Obandyella bykovae (Ais.), Globigerinoides bisphericus 
Todd., Globigerina praebulloides Blow, Melonis pompilioides (Ficht. et Moll), Asterigerinata planorbis (Orb.), Bolivina dilatata (Rss.), B. antiqua Orb., B. hebes MacFad., Bulimina elongata Orb., B. striata Orb., Pullenia bulloides (Orb.), Praeglobobulimina pyrula Orb., indikující prostředí vnějšího šelfu (např. Gilíková, Hladil eds et al. 2011b; Tomanová Petrová et al. 2018).

\subsection{Neogenní písek}

Polohy rezavěhnědého jemnozrnného silně světle slídnatého písku (vz. 4/18), slabě laminovaného, mají při horní hranici vrstvy vysrážen $\mathrm{CaCO}_{3}$ a obsahují velmi pestrou mikrofaunu: schránky foraminifer, ostny ježovek (?Eucidaris zeamays aj.), destičky a rotulu (?Schizechinus sp.), úlomky jehlic hub, četné fragmenty schránek měkkýšů a zoárií mechovek, červy - Ditrupa cornea (Linnaeus, 1758), Serpula sp., ?Serpulidae indet. (fragmenty schránek), brachiopody - Argyrotheca sp. (2 břišní misky, determinace konzultována s dr. M. A. Bitner, PAN Warszawa), členovce - fragment klepítka kraba a destička z krunýře (?), 1 ?zub obratlovce, úlomky korálů, kůstek, šupin a otolitů kostnatých ryb a ostrakodů. Reziduum kromě mikrofosilií tvoří úlomky hornin, oxidy a hydroxidy železa, zrna křemene, lupínky slídy, vzácně se vyskytují granáty a apatit.

\section{Foraminifery}

V hrubé písčité frakci jsou hojné taxony Amphistegina mammilla (Ficht. et Moll), Quinqueloculina sp., Planostegina costata (Orb.), Lenticulina calcar (L.), L. cultrata (Mont.), L. inornata (Orb.), v jemné frakci Asterigerinata planorbis (Orb.), Bolivina dilatata (Rss.), Bulimina schischkinskayae Sam., B. striata Orb., Elphidium crispum (L.), E. fichtelianum (Orb.) a další. Indikace pro stáří spodního badenu poskytuje výskyt jedinců druhu Orbulina suturalis Brön. Uvedená pseudoasociace pravděpodobně vznikla smísením mělkovodních druhů obývajících teplé laguny a mělká prríbřežní pásma vnitřního šelfu (amfisteginy, planosteginy, amfimorfiny) s druhy chladnomilnými a hlubokovodnějšími (lentikuliny, buliminy, boliviny) ve smyslu Murraye (2006).

\section{Mechovky}

Zkoumaný vzorek obsahoval vysoce diverzifikované společenstvo mechovek, celkem bylo identifikováno 38 taxonů.

Společenstvo se vyznačuje výrazně vyšší diverzitou cheilostomátních mechovek (29 taxonů) než cyklostomátních mechovek (9 taxonů). Z první skupiny převažují mechovky rodů Porella, Metrarabdotos, Margaretta a Reteporella, které svou životní strategií patří mezi tzv. K-stratégy. Takovéto rozložení taxonů je charakteristické pro klimaxové stadium mechovkového společenství (Zágoršek 2010).

Hojné zastoupení teplomilných taxonů (Metrarabdotos, Steginoporella, Myriapora) indikuje velice teplé, až subtropické podnebí (Moissette et al. 2007). Nektonní taxony rodu Cupuladria a Reussiela jsou charakteristické pro mělké a vysoce energetické prostředí, s tvrdým dnem, tzv. hard ground (Hakansson, Winston 1995). Tento předpoklad potvrzují i výskyty taxonů, žijících převážně v zóně vlnění, v sublitorální zóně (Margaretta a Reteporella), i vysoké procento zastoupení povlékavých druhů, charakteristických pro litorální zónu (kaloporidní taxony Onychocella i Porella).

\section{Měkkýši}

Fauna měkkýšů je poměrně početná a diverzifikovaná. Ve vzorku celkově převažují z mlžů pektinidi a ervilie, z plžů drobní gastropodi rodů Alvania a Bittium. Vzhledem ke špatnému zachování schránek (převaha neurčitelných fragmentů) však nelze asociaci přesněji kvantitativně vyhodnotit.

Nalezená asociace indikuje mořské prostředí, př̀ičemž př́tomnost stenohalinních elementů (např. Turritella spirata, Pectinidae, Arca, kelnatky aj.) spolu s téměř úplnou absencí brakických prvků (Hydrobia sp.) a s ohledem na výskyt ježovek a ramenonožců jednoznačně potvrzují, že salinita vody dosahovala normálních hodnot.

Ojedinělý nález terestrického gastropoda Vallonia sp. naznačuje blízkost pobřeží. Recentní zástupci tohoto rodu preferují spíše otevřená prostředí (louky apod. Mandic, Harzhauser 2003).

Měkkýší fauna svědčí o tom, že mořské prostředí bylo zřejmě spíše mělkovodní (sublitorál, resp. infralitorál - Turritella spirata, Anadara diluvii, Corbula gibba, Yoldia, Ostrea digitalina, Entalina tetragona aj.). Nalezené druhy drobných gastropodů (napřr. rodů Rissoa, Alvania a Bittium) většinou obývají mělké příbřežní zóny s porosty řas (Bagdasaryan et al. 1966; Tatishvili et al. 1968; Mandic et al. 2002; Kowalke, Harzhauser 2004).

O dobrém prokysličení vody nasvědčují kromě předpokládané přítomnosti porostů řas na dně i rozmanité životní strategie nalezených měkkýšů. Početné zastoupení bentosu vagilního (infauna - Nuculana, Venus, Ervilia aj., epifauna - pektinidi, kelnatky, drobní gastropodi) i sesilního (epifauna - Chama, Ostrea, infauna - Corbula) prokazuje bohaté osídlení substrátu, a to nejen na povrchu, nýbrž i uvnitř. Ve fauně se vyskytují jak požírači substrátu (Nuculana aj.), tak i filtrátoři (pektinidi, Anadara, Arca, Venus a další) - Dulai 1996 a Harzhauser 2002.

Jednotlivé druhy měkkýšů mají také různé požadavky na substrát. Většinou preferují substrát měkký, jílovitý (Anadara diluvii, Venus multilamella), písčitý (Chlamys, Callista, kelnatky) či písčito-jílovitý (Nucula nucleus, $\mathrm{Nu}$ culana fragilis, Corbula gibba, Alvania, Bittium) - Bagdasaryan et al. 1966; Tatishvili et al. 1968; Mandic et al. 2002; Kowalke Harzhauser 2004; Høisæter 2009. Přítomnost epibiontů, resp. sesilního bentosu (Chama, Ostrea aj.) ovšem naznačuje též - alespoň lokální - existenci substrátu pevného (skalnaté dno, rostlinstvo nebo schránky sesilního bentosu), což potvrzují i nálezy mechovek.

Zajímavý je nález 1 exempláře rodu Teredo, mlže zavrtávajícího se do mrtvého dřeva a živícího se celulózou, př́p. filtrováním suspenze z vodního sloupce (Mandic, Harzhauser 2003). Jeho přítomnost proto potvrzuje výskyt ponořených kusů dřeva na mořském dně. 
Nalezená asociace měkkýšů zahrnuje převážně teplomilné druhy.

$\mathrm{V}$ asociaci je řada průběžných miocenních druhů, na základě celkového charakteru měkkýší asociace a př́ítomnosti druhů Turritella spirata, Oopecten solarium a Papillicardium papillosum lze interpretovat stář́ jako badenské (Papp et al. 1978; Seitl 1981; Mandic 2004).

Shrnutí neogeních písků z pohledu paleontologie:

Písky obsahují diverzifikovaná a bohatá společenstva foraminifer, mechovek a měkkýšů. Z hlediska foraminifer se jedná o druhově odlišné společenstvo s početnější bentosní složkou oproti jílům, v nichž dominuje plankton. Došlo zde k smísení mělkovodních druhů obývajících teplé laguny a mělká příbřežní pásma vnitřního šelfu. Takto bohatý a diverzifikovaný paleontologický obsah není typický pro brněnské písky, nejčastější facii klastického spodního badenu na Brněnsku (např. Bubík, Petrová 2016; Tomanová Petrová et al. 2018). Doklad o mělkovodním mořském subtropickém prostředí podporují i nálezy schránek měkkýšů a zoárií mechovek.

\subsection{Prachovec}

V tělese jílů a písků byl uložen blok světle hnědobílého velmi silně vápnitého prachu až prachovce o velikosti asi $0,5 \times 1,0 \mathrm{~m}$, který ve vzorku $3 / 18$ obsahoval chudé společenstvo složené spíše $\mathrm{z}$ mělkovodních foraminifer, úlomků ostnů ježovek a zoárií mechovek.

\subsection{Písčitoprachovitý sediment (svahovina)}

Těleso sesuvu 2a (obr. 3) při jeho bázi tvoří polohy jílů a písků střídající se se svahovými sedimenty. Vzorky 7/18 a 8/18 jsou tvořené ostrohrannými úlomky hornin, křemenem, slídou, oxidy a hydroxidy železa, granáty, apatitem atd. Vedle palynomorf a foraminifer se ve výplavech objevovaly ostny ježovek, jehlice křemitých hub, úlomky schránek měkkýšů a zoárií mechovek.

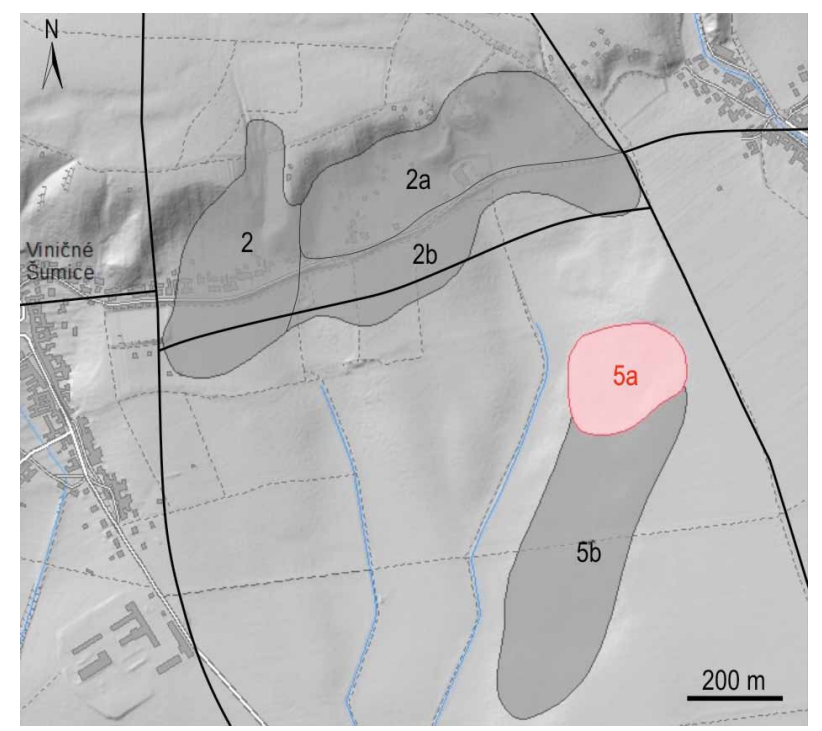

Obr. 3: Tělesa sesuvů vyznačená v digitálním modelu reliéfu 5G (zdroj Zabaged).

Fig. 3: Landslides depicted in the $5 \mathrm{G}$ digital relief model (source Zabaged).

\section{Foraminifery}

Z hlediska výskytu foraminifer byl početně i druhově pestřejší vzorek 7/18. Obsahoval častěji euryoxybiontní druh Bulimina elongata Orb. Oproti vzorkům 1/18, 2/18, 5/18 a 6/18 obsahoval méně planktonních taxonů, nicméně výskyt poškozené schránky Orbulina suturalis Brön. řadí společenstvo do spodního badenu. Dále se vyskytují běžně se ve spodním badenu nalézající druhy Melonis pompilioides (Ficht. et Moll), Elphidium crispum (L.), Globigerinoides trilobus (Rss.), Asterigerinata planorbis (Orb.), Bolivina dilatata (Rss.) atd.

\section{Palynomorfy}

Studované vzorky měly charakter promíchaných útržků jílovitých a prachovitých i hruběji klastických sedimentů. Vzorek 7/18 byl oproti vzorku 8/18 na palynomorfy výrazně bohatší. Determinováno bylo přes 170 zrn. Pylové spektrum obsahovalo velmi výrazný podíl taxonů, které se na našem území vyskytují pouze v sedimentech mladšího terciéru. Část taxonů má tercierní i kvartérní rozšírení. Nalezená pylová zrna mají různý stupeň zachování, projevující se př̀edevším odlišnou barvou, tlouštkou a stupněm degradace pylových obalů (exiny). Výsledné palynospektrum je s největší pravděpodobností směs kvartérních a terciérních palynomorf.

Převahu palynospektra tvořily konifery s létacími vaky - přes 100 zrn - (rody Pinus, Cathaya a méně Keteleeria, Picea, Cedrus). Zjištěny byly i cysty mořských obrněnek Dinoflagellata.

Určena byla zrna teplomilných taxonů Engelhardia, Platycarya, Cornus/Mastixia a stálezelené členy čeledi Fagaceae: Tricolporopollenites liblarencis a T. microhenrici. Arktotercierní, opadavé dřeviny byly zastoupeny rody Carya, Pterocarya, Celtis, Ostrya, Juglans, Betula a Quercus. Př́tomné byly elementy bažinných a lužních porostů: Taxodiaceae, Sciadopitys, Alnus, Lythraceae, Cyperaceae a spora Neogenisporites. Rod Olea a zástupci čeledí Poaceae, Caryophyllaceae a Brasicaceae představovaly světlomilnou vegetaci otevřenějších areálů (tab. 1).

Palynospektra s převahou konifer spolu s mořskými obrněnkami svědčí o sedimentaci v mořském prostředí, které je bud' vzdálenější od pobřeží, anebo vykazuje zvýšenou oxidaci, vůči které jsou konifery odolnější než většina dalších palynomorf (Havinga 1964; Heusser 1978). Obdobná palynospektra byla v sedimentech karpatské předhlubně typická pro sedimenty spodního badenu (Doláková et al. 2014; Holcová et al. 2015; Nehyba et al. 2016).

Některá determinovaná pylová zrna měla značně odlišný charakter zachování (vyšší degradace pylových obalů), který prokazuje fosilizaci v různém sedimentačním prostředí. Tento jev byl nápadný zejména u pylových zrn rodů Celtipollenites sp. a Juglanspollenites sp. Zástupci těchto rostlin (Celtis, Juglans) spolu s rodem Pterocarya přežívali na našem území i během spodno až střednopleistocenních interglaciálů. Poslední zaznamenaný výskyt byl v sedimentech interglaciálu holstein (Lang 1994; Litt et al. 2008; Urban et al. 2011). Z tohoto důvodu lze část palynomorf považovat za kvartérní - vyskytující se v teplém období max. do středního pleistocénu. 
Tab. 1: Přehled palynomorf $\mathrm{z}$ lokality Viničné Šumice, vzorky 7/18 a 8/18 z dokumentačního bodu BP381.

Tab. 1: Overview of palynomorphs from the Viničné Šumice locality, samples 7/18 and 8/18, reference point BP381.

\begin{tabular}{|c|c|c|c|}
\hline Taxony \dokumentační bod, č. vzorku & & BP381, 7/18 & BP381, 8/18 \\
\hline \multicolumn{4}{|l|}{ Taxony typické pouze pro terciér (neogén) } \\
\hline Types with branched projections & marine Dinophyta & 4 & \\
\hline Neogenisporis neogenicus Krutzsch, 1962 & Gleicheniaceae & 1 & \\
\hline Cathayapollenites krutzschi (Sivak, 1976) Planderová, 1990 & Cathaya sp. & 37 & 4 \\
\hline Keteleeriapollenites dubius (Chlonova, 1960) Slodkowska, 1994 & Keteleeria & 4 & \\
\hline Cedripites miocaenicus Krutzsch, 1971 & Cedrus & 3 & 1 \\
\hline Sciadopityspollenites serratus (Potonié \& Venitz, 1934) Raatz, 1937 & Sciadopitys & 1 & \\
\hline $\begin{array}{l}\text { Inaperturopollenites hiatus (Potonié) Thomson \& Pflug; I. concepidites } \\
\text { (Wodehouse) Krutzsch }\end{array}$ & Taxodium, Glyptostrobus & 1 & \\
\hline Ostryapollenites rhenanus (Thomson, 1950) Nagy, 1969 & Ostrya, Ostryopsis & 1 & \\
\hline Minutipollis gen. indet. & Caryophyllaceae & & 1 \\
\hline Quercoidites microhenrici (Potonié, 1931) Potonié, Thomson, Thiergart., 1950 & Fagaceae & 1 & 1 \\
\hline Tricolporopollenites liblarensis (Thomson, 1950) Grabowska, 1994 & Fagaceae & 3 & 1 \\
\hline $\begin{array}{l}\text { Engelhardtioidites punctatus (Potonié, 1931) Potonié, } 1951 \text { ex Potonié, 1960, } \\
\text { E. quietus (Potonié, 1931) Potonié, 1951 }\end{array}$ & Engelhardtia & 2 & \\
\hline Platycaryapollenites miocaenicus Nagy, 1969 & Platycarya & 1 & \\
\hline Oleaidearumpollenites sp. & Oleaceae & 1 & \\
\hline \multicolumn{4}{|c|}{ Taxony vyskytující se v neogénu i kvartéru nebo přecházejí do některých max. střednopleistocenních interglaciálů } \\
\hline Botryococcus braunii Kützing, 1969 & Botryococcus & & 1 \\
\hline Pinus haploxylon and sylvestris types & Pinus & více než 100 & 14 \\
\hline Piceapollis sp. & Picea & 1 & \\
\hline Alnipollenites verus (Potonié, 1931 ex Potonié, 1960) & Alnus & 1 & \\
\hline Betulaepollenites betuloides (Pflug, 1953) Nagy, 1969 & Betula & 1 & \\
\hline $\begin{array}{l}\text { Quercoidites sp., Q. granulatus (Nagy, 1969) Slodkowska, 1994, Q. asper } \\
\text { (Pflug \&Thomson, 1953) Slodkowska, } 1994\end{array}$ & Quercus & 2 & \\
\hline Faguspollenites verus Raatz, 1937 & Fagus & & \\
\hline Caryapollenites simplex (Potonié, 1931) Raatz, 1937 & Carya & 1 & 1 \\
\hline Pterocaryapollenites stellatus (Potonié, 1931) Thiergart, 1937 & Pterocarya/Cyclocarya & 1 & \\
\hline Juglanspollenites verus Raatz, 1937 & Juglans & 3 & \\
\hline Lythraceaepollenites sp. & Lythraceae & 1 & \\
\hline Fraxinoipollenites sp. & Fraxinus & 2 & \\
\hline Salixipollenites sp. & Salix & 1 & \\
\hline Celtipollenites sp. & Celtis & 2 & \\
\hline \multirow[t]{2}{*}{ Graminides sp. } & Poaceae & 1 & 1 \\
\hline & kubic caves & & $\mathrm{x}$ \\
\hline
\end{tabular}

\section{Charakteristika sesuvného území}

Šírka celého sesuvného území (obr. 3) činí cca $1095 \mathrm{~m}$ a jeho největší délka je cca $550 \mathrm{~m}$. Plocha celého sesuvného území činí $316390 \mathrm{~m}^{2}$. Nejvyšší bod sesuvu představuje jeho koruna (crown - vše podle Krauter et al. 1993), která dosahuje $375 \mathrm{~m} \mathrm{n}$. m., nejnižší bod je $280 \mathrm{~m}$ n. m. (toe). Odlučná část sesuvného území (main scarp) je prakticky bez kvartérní a miocenních sedimentů a vycházejí v ní horniny kulmu. Odlučná část leží na strmém svahu se sklonem $21^{\circ}$. Místy se v ní vyskytují strmé skalní výchozy postižené gravitačním rozpadem. Při jejím ukončení se prudce mění sklon svahu. Začíná zde akumulační část (main body), která má nejvy̌̌ší bod $327 \mathrm{~m} \mathrm{n}$. m. (top) a má sklon svahu $8^{\circ}$.

\section{Diskuze}

Interakce mezi varisky konsolidovaným fundamentem a prohlubující se transgresí v badenském sedimentačním prostoru před čelem nasouvaných flyšových Karpat měly za následek vznik četných synsedimentárních sesuvů, které lze dokumentovat např́klad v oblasti kry Maleníka (Krejčí et al. 2008; Jankovská et al. 2018).
Všechny sesuvy, spojené s vývojem svahů jv. okraje Drahanské vrchoviny, nebyly však dosud detailně zmapovány a zaneseny do Registru svahových nestabilit České geologické služby (www.geology.cz/svahovenestability).

Lokalita studované svahové nestability př̀ v. okraji Viničných Šumic představuje komplexní sesuvné území evidenčního čísla 25-41-23/2 v Registru svahových nestabilit ČGS, které sestává $\mathrm{z}$ několika dílč́ch sesuvů (obr. 3). Pro jejich přesné prostorové vymezení byla použita data digitálního modelu reliéfu 5. generace, která jsou zapůjčena do ČGS z Českého úřadu zeměměřického a kartografického.

Z hlediska typu sesuvu (Hungr et al. 2014) se jedná v první etapě vzniku o translační blokový posun (translational block slide), kde mezi dvěma sz.-jv. orientovanými zlomy došlo k poklesu podložní kry a posunu sedimentů neogénu (sesuv č. $2 \mathrm{~b}$ na obr. 3). Odlučná část tohoto sesuvu je dnes překrytá sesuvem 2a. Po ústupu mořské hladiny se na povrchu sedimentů badenu vytvořil půdní profil a během dalšího výzdvihu okrajů Drahanské vrchoviny se na jejich j. svazích vytvořil nerovnovážný stav. Poté došlo $\mathrm{k}$ dalšímu sesouvání podél rotační smykové plochy, 
kdy se na půdní profil sesunula vyšší lamela sesuvu (rock slump; sesuv č. 2a). V odlučné hraně tohoto sesuvu došlo k odkrytí sedimentů kulmu. Tento frontální sesuv má délku $220 \mathrm{~m}$ a šírku $735 \mathrm{~m}$. V půdním profilu v podloží sesuvu 2a nebyly nalezeny mladší paleontologické doklady než střední pleistocén, $\mathrm{z}$ čehož lze usuzovat na to, že stáří tohoto mladšího sesuvu v nadloží sesuvu $2 \mathrm{~b}$ je střednopleistocenní a mladší. Pokud dochází v prostoru karpatské předhlubně $\mathrm{k}$ pleistocenním pohybům na sedimenty neogénu, pak bývají zachovány četné paleontologické doklady $\mathrm{v}$ sedimentech pro interval mezi podložními neogenními sedimenty a stárím samotného sesuvného pohybu (Jankovská et al. 2018). Na této lokalitě byly takové nálezy určeny a doloženy, podle nálezu neogenní mikroflóry a mikrofauny lze předpokládat redepozice do svahových sedimentů v různém časovém sledu. Sesunutím dílčího sesuvu 2a byl vývoj střednopleistocenních svahových sedimentů ukončen.

Nejmladší etapu sesouvání představuje dílčí proudový sesuv číslo 2 (obr. 3), kde je již vlivem mladších gravitačních pohybů setřen rozdíl mezí spodní a horní lamelou svahové deformace. Tento sesuv bez bližšího určení lze datovat již do kvartéru.

Maximální mocnost celé komplexní sesuvné akumulace lze stěží určit pro nedostatek objektivních dat, protože z oblasti nejsou známy výsledky žádného inženýrskogeologického průzkumu. Podle rozměrů a stavby sesuvného tělesa lze uvažovat, že hloubka celé sesuvné akumulace může dosahovat místy i přes $20 \mathrm{~m}$.

\section{Závěr}

Deformované jíly situované na svazích Drahanské vrchoviny mezi obcemi Viničné Šumice a Vítovice se nacházejí v okolí z. okrajového zlomového systému karpatské předhlubně. Tento zlomový systém je porušený mladšími příčnými zlomy SSZ-JJV, podél kterých některé dílčí kry jsou vzájemně pokleslé podle výsledků výše uvedených vrtů až o více než $100 \mathrm{~m}$. Různá mocnost pískových poloh a změny směru sklonu vrstevnatosti ukazují, že nový výchoz odkryl profil bazální části vyšší kry rozsáhlého sesuvu. Hnědobílé prachovce pravděpodobně představují bloky a úlomky napadané ze strmého svahu na půdní profil a svahové sedimenty na povrchu jílových sedimentů spodního badenu. Svahovými pohyby pak došlo k promíchání nálezů z období badenu a kvartéru. Vývoj těchto sedimentů byl ve středním pleistocénu ukončen nasunutím rozsáhlého dílčího sesuvu.

$\mathrm{V}$ sedimentech byly doloženy také palynomorfy pocházející ze střednopleistocenních interglaciálů, příp. starších, které dokládají pozdně střednopleistocenní svahové pohyby.

\section{Poděkování}

Předložená práce vznikla za finanční podpory interního projektu České geologické služby číslo 321070 („Registr svahových nestabilit"). Palynologické analýzy byly podpořeny Specifickým výzkumem (1344) Ústavu geologických věd MU Brno a výzkum měkkýšu projektem ESH CZ.1.07/2.3.00/20.0166 „Centrum teorie vzdèlávání přirodovědných oborü“ (PdF UP Olomouc).

Velké diky patři kolegovi Mgr. Martinovi Palečkovi za př́pravu dat a obrázků. Autoři rovněž děkují handling editorovi doc. Mgr. Martinovi Ivanovovi, Dr. a recenzentüm prof. RNDr. Rostislavovi Brzobohatému, CSc. a Mgr. Ivo Baroňovi, Ph.D.

\section{Literatura}

Adamová, M., Dornič, J., Dvořák, J., Štych, J. (1975). Hlubinný vrt Rousínov Ro-1. - MS, ČGS-Geofond Praha.

Bagdasaryan, K. G., Tatishvili, K. G., Kazachashvili, Z. R., Muschelishvili, L. V. et al. (1966). Spravochnik po ekologii morskich dvustvorok. - Nauka, 71-79. Moskva.

Berggren, W. A., Kent, D. V., Swisher, C. C., III., Aubry, M.-P. (1995). A revised Cenozoic geochronology and chronostratigraphy. - SEPM (Society of Sedimentary Geology), SEPM Special Publication, 54, 129-212.

Blížkovský, M., Mašín, J., Mátlová, E., Mitrenga, P., Novotný, A., Pokorný, L., Rejl, L., Šalanský, K. (1988). Lineární struktury čs. části Českého masívu podle geofyzikálních indikací. - Věstník Ústředního ústavu geologického, 63, 5, 275-290.

Brzobohatý, R. ed. (1989). Základní geologická mapa 1:25 000, list 24-414 Vyškov. - MS, ČGS-Geofond Praha.

Bubík, M., Petrová, P. (2004). Foraminifery brněnských písků ve vrtu Černovice TGB-1. - Geologické výzkumy na Moravě a ve Slezsku v roce 2003, 14-17.

Doláková, N., Holcová, K., Nehyba, S., Hladilová, Š., Brzobohatý, R., Zágoršek, K., Hrabovský, J., Seko, M., Utescher, T. (2014). The Badenian parastratotype at Židlochovice from the perspective of high resolution stratigraphy. - Neues Jahrbuch für Geologie und Paläontologie - Abhandlungen, 271, 2, 169-201. https://doi.org/10.1127/0077-7749/2014/0383

Dulai, A. (1996). Taxonomic composition and palaeoecological features of the Early Badenian (Middle Miocene) bivalve fauna of Szob (Börzsöny Mts, Hungary). - Annales historico-natutrales Musei Nationalis Hungarici, 88, 31-56. 
Gilíková, H., Hladil, J. (eds), J., Bubík, M., Černý, J., Hrdličková, K., Kunceová, E., Melichar, R., Otava, J., Tomanová Petrová, P., Vít, J. (2011a). Základní geologická mapa České republiky 1 : 25 000, list 24-413 Mokrá-Horákov. - MS, Česká geologická služba Praha.

Gilíková, H., Hladil, J., Bubík, M., Černý, J., Buriánek, D., Dvořák, J., Faměra, M., Havíř, J., Hrdličková, K., Kalvoda, J., Konečný, F., Kociánová, L., Kováčik, M., Kryštofová, E., Krumlová, H., Kumpan, T., Kunceová, E., Maštera, L., Melichar, R., Müller, P., Nehyba, S., Otava, J., Pecina, V., Pecka, T., Tomanová Petrová, P., Poul, I., Poulová, D., Rez, J., Skácelová, D., Skácelová, Z., Slobodník, M., Šikula, J., Šrámek, J., Večeřa, J., Vít, J., Weiner, T. (2011b). Vysvětlivky k základní geologické mapě ČR $1: 25$ 000, list 24-413 Mokrá-Horákov. - MS, Česká geologická služba Praha.

Hakansson, E., Winston, J. E. (1995). Interstitial Bryozoans: Unexpected Life Forms in a High Energy Environment. - In: Nielsen, C., Larwood, G. P. (eds): Bryozoa: Ordovician to recent. Olsen \& Olsen Fredeiisborg, Denmark, 125-134.

Harzhauser, M. (2002). Scaphopoda aus dem Karpatium (Untermiozän) des Korneuburger Beckens (Niederösterreich). - In: Sovis W., Schmid B. (eds) Das Karpat des Korneubuger Beckens, Teil 2, 205-214. Wien.

Havinga, A. J. (1964). Investigation into the differential corrosion susceptibility of pollen and spores. - Pollen et Spores, 6, 621-635. Heusser, L. (1978). Spores and pollen in the marine realm. - In: Haq, B. U., Boersma, A. (eds): Introduction to marine micropaleontology, 327-339, Elsevier Science.

Holcová, K., Hrabovský, J., Nehyba, S., Hladilová, Š., Doláková, N., Demeny, A. (2015). The Langhian (Middle Badenian) Carbonate Production Event in the Moravian Part of the Carpathian Foredeep (Central Paratethys): A Multiproxy Record. - Facies, 61, 1, 1-26. https://doi.org/10.1007/s10347-014-0419-Z

Høisæter, T. (2009). Distribution of marine, benthic, shell bearing gastropods along the Norwegian coast. - Fauna norvegica, 28, 1, 5-106. https://doi.org/10.5324/fn.v28i0.563

Hungr, O., Leroueil, S., Picarelli, L. (2014). The Varnes classification of landslide types, an update. - Landslides, 11, 167-194. https://doi.org/10.1007/s10346-013-0436-y

Jankovská, V., Baroň, I., Nývlt, D., Krejčí, O., Krejčí, V. (2018). Last Glacial to Holocene vegetation succession recorded in polyphase slope-failure deposits on the Maleník Ridge, Outer Western Carpathians. - Quaternary International, 470, 38-52. https://doi.org/10.1016/j.quaint.2017.10.048

Kowalke, T., Harzhauser, M. (2004). Early ontogeny and palaeoecology of the Mid-Miocene rissoid gastropods of the Central Paratethys. - Acta Palaeontologica Polonica, 49, 1, 111-134.

Krauter, E., Beltran, L., Cruden, D. M., Lefèbvre, G., Ter-Stepanien, G. I., Zhouyan, Z. (1993). Multilingual landslide glossary. The International Geotechnical Societies UNESCO. Working Party for World Landslide Inventory. Richmond. The Canadian Geotechnical Society.

Krejčí, O., Baroň, I., Hubatka, F., Kašperáková, D., Nývlt, D. (2008). Tectonic of slopes with large block landslides on the NE margin of the Bohemian Massif. - In: Jaboyedoff, M. (ed.): Congress Slope-Tectonics 2008, Lausanne, February 15th-16th, 2008, Université de Lausanne, Institut de géomatique et d'analyse risque. Lausanne.

Lang, G. (1994). Quartäre Vegetationsgeschichte Europas. - Gustav Fischer Verlag, Jena-Stuttgart-New York.

Litt, T., Shmincke, H. U., Frechen, M., Schluchter, Ch. (2008). Quaternary. - In: McCann, T. (ed.): The Geology of Central Europe. Vol. 2 Mesozoic and Cenozoic, Geologic Society London, 1288-1340.

Mandic, O. (2004). Pectinid bivalves from the Grund Formation (Lower Badenian, Middle Miocene, Alpine-Carpathian Foredeep) - taxonomic revision and stratigraphic significance. - Geologica Carpathica, 55, 2, 129-146.

Mandic, O., Harzhauser, M. (2003). Molluscs from the Badenian of the Gaindorf Formation. - Annalen des Naturhistorischen Museums in Wien, 104A, 85-128.

Mandic, O., Harzhauser, M., Spezzaferri, S., Zuschin, M. (2002). The paleoenvironment of an early Middle Miocene Paratethys sequence in NE Austria with special emphasis on paleoecology of mollusks and foraminifera. - Geobios, 35, 1, $193-206$. https://doi.org/10.1016/S0016-6995(02)00059-1

Moissette, P., Dulai, A., Escarguel, G., Kázmér, M., Müller, P., Saint Martin, J. P. (2007). Mosaic of environments recorded by bryozoan faunas from the Middle Miocene of Hungary. Palaeogeography, Palaeoclimatology, Palaeoecology, 252, 530-556. https://doi.org/10.1016/j.palaeo.2007.05.010

Murray, J. (2006). Ecology and Applications of Benthic Foraminifera. - Cambridge University Press, 426 pp.

Nehyba, S., Holcová, K., Gedl, P., Doláková, N. (2016). The Lower Badenian transgressive-regressive cycles - a case study from Oslavany (Carpathian Foredeep, Czech Republic). - Neues Jahrbuch für Geologie und Paläontologie - Abhandlungen, 279, 2, 209-238. https://doi.org/10.1127/njgpa/2016/0548

Papp, A., Cicha, I., Seneš, J., Steininger, F. et al. (1978). M4 Badenien (Moravien, Wielicien, Kosovien). - Chronostratigraphie und Neostratotypen, Bd. VI, VEDA, Bratislava.

Seitl, L. (1981). Měkkýší fauna lokality Borač. - Časopis Moravského muzea, 66, 1, 33-50.

Skoupilová, N. (1974). Doplňující zpráva hydrogeologického průzkumu akce obecní vodovod - Viničné Šumice. - MS, ČGS-Geofond Praha.

Tatishvili, K. G., Bagdasaryan, K.G., Kazachashvili, Z. R. (1968): Spravochnik po ekologii morskich bryuchonogich. - Nauka, 54-55. Moskva.

Tomanová Petrová, P., Nehyba, S., Diviš, K., Hladilová, Š., Gregorová, R., Vít, J., Hudec, P. (2018). Paleoprostředí ve spodním badenu na severním okraji Brna (Divišova čtvrt'). - Geologické výzkumy na Moravě a ve Slezsku, 25, 1-2, 65-72.

Urban, B., Sierralta, M., Frechen, M. (2011). New evidence for vegetation development and timing of Upper Middle Pleistocene interglacials in Northern Germany and tentative correlations. - Quaternary International, 241, 125-142. https://doi. org/10.1016/j.quaint.2011.02.034

Zágoršek, K. (2010). Bryozoa from the Langhian (Miocene) of the Czech Republic. - Acta Musei Nationalis Pragae, Series B Historia Naturalis, 66, 1-4, 1-255. 